\title{
Antagonism of Trichoderma asperellum Isolates against Macrophomina phaseolina Causing Soybean Charcoal Rot and Its Impact on Physiological Parameters of Crop
}

\author{
Ishwar Patidar ${ }^{*}$ and Vibha ${ }^{2}$ \\ ${ }^{1}$ Department of Plant Pathology, ${ }^{2}$ Department of Plant Physiology, Jawaharlal Nehru Krishi \\ Vishwa Vidyalaya, Jabalpur (M.P.) 482 004, India \\ *Corresponding author
}

\section{A B S T R A C T}

\begin{tabular}{|l|}
\hline Ke y w o r d s \\
$\begin{array}{l}\text { Fungal isolates, } \\
\text { Charcoal rot, } \\
\text { Physiological } \\
\text { parameters and disease } \\
\text { incidence }\end{array}$ \\
\hline Article Info \\
\hline $\begin{array}{l}\text { Accepted: } \\
\text { 10 July 2018 } \\
\text { Available Online: } \\
\text { 10 August } 2018\end{array}$ \\
\hline
\end{tabular}

Soybean (Glycine max) is a miracle crop due to its extraordinary qualities apart from known for rich source of vegetable protein and oil. Over the years, its production is stagnant or declining owing to climate change and also due to ever changing pathogenic behaviour of Macrophomina phaseolina. The present investigation was undertaken to utilize the dominant resident mycoflora of crop that are capable of adjusting to changing environment apart from its ability to combat the menace of its co-partner (pathogenic group) evolving with them. Dominant rhizosphere fungi viz. Trichoderma asperellum and its ten isolates were isolate d through dilution plate technique. Efficacy of Trichoderma asperellum isolates against $M$. phaseolina was established through dual culture and poison food technique. Under in-vivo conditions, their impact on physiological parameters and disease suppression ability has also been established. The isolates with higher mycelia growth suppressing ability under dual culture technique had not found inhibitory towards the test pathogen under poison food technique. Similarly, T. asperellum isolates tested under in-vitro showed their varying potential against pathogenic fungi under in-vivo conditions.

\section{Introduction}

Soybean is a miracle crop due to its extraordinary qualities as it contains about 40 percent protein, 29 percent carbohydrate and 20 percent oil. Its oil comprises of 85percent unsaturated cholesterol free fatty acid with essential nutrients (Aditya et al., 2011). Charcoal rot caused by Macrophomina phaseolina (Tassi) Goidanich is one of the most important diseases of soybean in tropical and subtropical regions of the world that results in reduced yield and poor seed quality. The pathogen is a cosmopolitan soil saprophyte and is well known facultative, opportunistic plant pathogen that infects plants exposed to certain stress conditions (Tesso et al., 2005). This disease leads to early maturation, chlorosis and incomplete pod filling. Owing to higher variability among the 
isolates of its pathogen, no commercial resistant soybean variety is yet available for effective management of this disease. The diversity among the genus Trichoderma is great and is considered as potential biocontrol and plant growth promoting fungi for many crops (Verma et al., 2007; Bai et al., 2008; Savazzini et al., 2009). Effective biocontrol of Macrophomina phaseolina by Trichoderma species along with several other soil-borne fungi are widely established [1] besides their abilities to enhance systemic resistance system of plant against diseases [2]. Significant effect of defense enzymes such as peroxidase, polyphenol oxidase, and phenylalanine ammonia lyase produced by $T$. viride alone or in combination with Pseudomonas fluorescens against $M$. phaseolina in green-gram plants has also been reported by Thilagavathi and coworkers (2007). Similarly, tomato plants primed with $T$. arundinaceum triggered the expression of defense-related genes belonging to the salicylic acid (SA) and jasmonic acid (JA) pathways in presence of Botrytis cinerea and Rhizoctonia solani (Malmierca et al., 2012). The toxin (phaseolinone) produced by M. phaseolina (Tassi) Goidanich causes vascular blockage that ultimately led to destruction of plant organs. This pathogen is also considered as high-temperature pathogen because disease severity increases as the air and soil temperatures increase from 28 to $35^{\circ} \mathrm{C}$ vis à vis low soil moisture (Pearson et al., 1984; Gary et al., 1991). Management of charcoal rot disease is difficult due to nature of pathogen and rejection of chemical control methods owing to environmental and health issues. Trichoderma species are saprophytic, widely distributed, quick grower, with high population densities in soils and plant residues. They are easy to culture and can produce large amounts of conidia with long life time (Manczinger et al., 2002). Hence, present investigation was undertaken with objectives (i) to establish variability among potential native isolates of $T$. asperellum on the basis of their qualitative attributes and (ii) to determine role of $T$. asperellum isolates against Macrophomina phaseolina under invitro and in-vivo conditions along with their impact on physiological parameters of crop.

\section{Materials and Methods}

Collection of diseased specimens and purification of the pathogens

Diseased soybean plants exhibiting typical symptoms of charcoal rot incidence levels were collected from the sick plots of AICRP on soybean experimental field of Jawaharlal Nehru Krishi Vishwa Vidyalaya (22 ${ }^{\circ} 9^{\prime}-22^{0}$ $80^{\prime} \mathrm{N}$; 78 $\left.21^{\prime}-8^{\circ} 58^{\prime} \mathrm{E}\right)$, Jabalpur in the Central India during 2015-16. The pathogen was isolate $\mathrm{d}$ and further purified through hyphal tip method and sub-cultured on PDA slants at $4{ }^{\circ} \mathrm{C}$ for further use. Dilution plate method was used to isolate the $T$. asperellum isolates from soil samples of soybean plant showing different level of charcoal rot symptom, on Rose Bengal Agar medium (RBA). Plates with RBA medium was added with $0.1 \mathrm{ml}\left(=10^{-4}\right)$ of suspension and incubated at $22 \pm 2^{0} \mathrm{C}$ for 15 days. The colonies were transferred to test tubes containing Potato Dextrose Agar (PDA) medium. The $T$. asperilum isolates were designated as TA1, TA2, TA3, TA4, TA5, TA6, TA7, TA8, TA9, and TA10, throughout the study.

\section{Evaluation of antagonistic potential of beneficial fungi in-vitro}

The antagonistic potentials of $T$. asperillum isolates were evaluated against the $M$. phaseolina through dual culture technique (Denis and Webster, 1971). A five mm disc of different fungal isolates was cut out from the seven days old culture and placed close to one end of the Petri-plate containing $20 \mathrm{ml}$ solidified PDA medium. At the opposite end, 
a similar disc from the culture of the pathogen $M$. phaseolina was placed simultaneously. The Petri-plates were incubated at $25 \pm 2^{\circ} \mathrm{C}$ in a BOD incubator and the inhibition of the growth of the pathogen by the antagonistic fungi was measured after $48 \mathrm{hrs}, 72 \mathrm{hrs}$. and $96 \mathrm{hrs}$. Of incubation till both occupies the entire space of Petri-plate.

Culture filtrate of TA isolates grown in PDA broth grown for 10 days were collected after passing it twice through Whatman filter paper No. 1. These filtrates were used to amend Petri-plates containing PDA at 5 per cent concentration and incubated at $25+2^{\circ} \mathrm{C}$ and observations were recorded after 48, 72, and 96, hours, respectively; an un-amended Petriplate served as check (control). Each treatment was replicated thrice and the experiment was repeated twice.

The antagonism was measured on the basis of inhibition of the pathogen by the bio agent by the following formulae

Radial growth in control (C) Radial growth in the treatment $(\mathrm{T})$ Inhibition $=$

Radial growth in control(C)

Assessment of antagonistic potential of $T$. asperillum isolates under in-vivo conditions

The inoculum of fungus $M$. phaseolina was produced on sand + wheat flour mix (9:1), moistened with water and autoclave twice for 90 minutes on two consecutive days. Thirty days after the sowing of the seeds, the culture filtrate of individual beneficial fungi were added into the pots that were already containing the $M$. phaseolina inoculum spreaded on sand + wheat flour mix (@ $5 \mathrm{gm} /$ $\mathrm{kg}$ of potting mix). Two sets of experiments with three replicates for each treatment were maintained. The experiment was done in two sets in two different poly-houses. Ten soybean seeds were sown in each clean pot at the 2-3 $\mathrm{cm}$ deep in six pots for each strain of $T$. asperillum along with un-inoculated control.

\section{Relative water content (RWC)}

Measurements of RWC (Barrs and Weatherly, 1962) were performed on leaves collected from soybean plants. Individual leaves were first removed from the stem with tweezers and were weighed immediately (fresh mass, FM) to obtain minimum 0.5 gram from each sample.

In order to obtain the turgid mass (TM), leaves were floated in distilled water inside a closed Petri dish. At the end of the imbibition period, leaf samples were placed in a pre-heated oven at $80{ }^{\circ} \mathrm{C}$ for $48 \mathrm{hr}$. to obtain the dry mass (DM). Values of FM, TM, and DM were used to calculate RWC, using the following equation:

$\operatorname{RWC}(\%)=[(\mathrm{FM}-\mathrm{DM}) /(\mathrm{TM}-\mathrm{DM})] \times 100$

\section{Chlorophyll content index}

Chlorophyll Content Index was estimated through the portable chlorophyll meter Peng et al., (1992). Fully expanded leaf sample from three places of each plant of different treatments has been selected for estimation of chlorophyll content index. The mean of triplicate readings taken using SPAD-502 (SPAD-502, Minolta, Japan) around the midpoint near the midrib of each sample were recorded for different treatment of chickpea leaf and averaged.

\section{Disease incidence}

The percent of charcoal rot incidence of each treatment was calculated by using following formulae.

Disease incidence $(\%)=$ No. of plants exhibiting wilt symptom X 100 


\section{Results and Discussion}

Evaluation of T. asperellum isolates against M. phaseolina under in-vitro conditions

The effects of ten isolates of $T$. asperellum were assessed for the inhibition of mycelial growth of M. phaselina. It is evident from the (Table 1) that all the isolates were highly suppressive towards the test pathogen. The suppression of mycelial growth of $M$. phaselina by different isolates of $T$. asperellum varied between $30.75 \mathrm{~mm}$ to $39.34 \mathrm{~mm}$. The highest $(30.75 \mathrm{~mm})$ inhibition was recorded with isolate 1 while least $(39.34 \mathrm{~mm})$ with isolate 7 . The isolate 1 $(30.75 \mathrm{~mm})$, isolate $4(30.96 \mathrm{~mm})$, isolate 5 (38.37), and isolate 10 (38.68) were equally suppressive towards the test pathogen and were next best to isolate $6(31.56 \mathrm{~mm}), 9$ (33.11), 2 (35.51) and isolate 8 (37.33). There was retrogressive significant increase in growth of the pathogen was recorded at every interval of time. The highest $(36.44 \mathrm{~mm})$ inhibition of $M$. phaseolina was recorded in cell free culture filtrate of isolate 6 followed by isolate $8(38.43)$, isolate $3(38.69 \mathrm{~mm})$, isolate 1 (41.87), isolate 7 (42.64) and isolate 2 (43.31) under poison food technique (Table 2).

Impact of $T$. asperellum isolates on physiological parameters and disease incidence under in-vivo conditions

The effects of culture filtrate of different isolates of T. asperellum were tested under invivo conditions on relative water content (RWC), chlorophyll content (SPAD-502) and on disease incidence (Table 3).

The highest (79.28 \%) RWC was recorded in isolate 9 treated plants followed isolate 5 $(75.69 \%)$, isolate $1(67.32 \%)$ and isolate 3 $(61.35 \%)$. Similarly, the lowest $(16.66 \%)$ disease incidence was recorded in isolate 9 treated plants.

Identical but higher disease suppression was also recorded in isolate 5 (23.07) and isolate 1 (23.07\%) followed by isolate $3(28.57 \%)$.

Table.1 Evaluation of Trichoderma asperellum isolates against M. phaseolina through dual culture technique

\begin{tabular}{|c|c|c|c|c|}
\hline S. No. & Trichodrma & \multicolumn{3}{|c|}{ Growth inhibition (in mm) } \\
\hline & asperellum & $\mathbf{4 8}$ hours & $\mathbf{7 2}$ hours & $\mathbf{9 6}$ hours \\
\hline 1. & Isolate 1 & 17.0 & 27.0 & 35.7 \\
\hline 2. & Isolate 2 & 24.0 & 35.0 & 43.0 \\
\hline 3. & Isolate 3 & 29.7 & 37.3 & 46.3 \\
\hline 4. & Isolate 4 & 16.3 & 26.0 & 38.7 \\
\hline 5. & Isolate 5 & 30.7 & 39.3 & 46.0 \\
\hline 6. & Isolate 6 & 18.0 & 30.3 & 35.0 \\
\hline 7. & Isolate 7 & 31.7 & 41.0 & 48.3 \\
\hline 8. & Isolate 8 & 30.7 & 37.3 & 42.7 \\
\hline 9. & Isolate 9 & 21.0 & 32.3 & 37.0 \\
\hline 10. & Isolate 10 & 30.0 & 40.3 & 47.3 \\
\hline & Control & $\mathbf{4 0 . 7}$ & $\mathbf{5 7 . 4}$ & $\mathbf{7 5 . 5}$ \\
\hline & SE m \pm & 0.54 & 0.50 & 0.43 \\
\hline & CD at (5\%) & 1.61 & 1.49 & 1.28 \\
\hline & $\mathrm{CV}$ & 3.63 & 2.47 & 1.73 \\
\hline
\end{tabular}


Table.2 Screening of Trichoderma asperellum isolates against $M$. phaseolina through poison food technique

\begin{tabular}{|c|c|c|c|c|}
\hline \multirow[t]{2}{*}{ S. No. } & \multirow{2}{*}{$\begin{array}{c}\text { Trichoderma } \\
\text { asperellum }\end{array}$} & \multicolumn{3}{|c|}{ Growth inhibition (in mm) } \\
\hline & & 48 hours & 72 hours & 96 hours \\
\hline 1. & Isolate 1 & 34.7 & 41.7 & 57.7 \\
\hline 2. & Isolate 2 & 37.7 & 42.3 & 61.3 \\
\hline 3. & Isolate 3 & 25.3 & 37.3 & 55.7 \\
\hline 4. & Isolate 4 & 36.0 & 44.0 & 62.7 \\
\hline 5. & Isolate 5 & 37.3 & 45.0 & 64.0 \\
\hline 6. & Isolate 6 & 18.3 & 39.3 & 50.3 \\
\hline 7. & Isolate 7 & 33.0 & 43.0 & 62.3 \\
\hline 8. & Isolate 8 & 22.7 & 40.7 & 54.0 \\
\hline 9. & Isolate 9 & 33.3 & 45.7 & 64.7 \\
\hline 10. & Isolate 10 & 32.0 & 47.7 & 65.0 \\
\hline & Control & 40.7 & 57.4 & 75.5 \\
\hline & $\mathrm{SE} \mathrm{m} \pm$ & 0.42 & 0.46 & 0.37 \\
\hline & $\mathrm{CD}$ at $(5 \%)$ & 1.27 & 1.37 & 1.11 \\
\hline & $\mathrm{CV}$ & 2.32 & 1.81 & 1.06 \\
\hline
\end{tabular}

Table.3 Impact of Trichoderma asperellum isolates on physiological parameters and disease incidence of soybean

\begin{tabular}{|c|c|c|c|c|c|c|}
\hline \multirow{2}{*}{$\begin{array}{l}\text { S. } \\
\text { No. }\end{array}$} & \multirow{2}{*}{$\begin{array}{c}\text { Trichoderma } \\
\text { asperellum }\end{array}$} & \multirow{2}{*}{$\begin{array}{c}\text { RWC } \\
(\%)\end{array}$} & \multicolumn{3}{|c|}{ Chlorophyll content (SPAD-502) } & \multirow{2}{*}{$\begin{array}{c}\text { Disease } \\
\text { incidence } \\
(\%)\end{array}$} \\
\hline & & & BI & AI & Loss $(\%)$ & \\
\hline 1. & Isolate 1 & 67.32 & 32.0 & 27.2 & 70.0 & 23.07 \\
\hline 2. & Isolate 2 & 47.27 & 30.9 & 28.9 & 69.1 & 44.44 \\
\hline 3. & Isolate 3 & 61.35 & 27.3 & 27.9 & 72.7 & 28.57 \\
\hline 4. & Isolate 4 & 55.87 & 28.5 & 18.9 & 71.5 & 33.33 \\
\hline 5. & Isolate 5 & 75.69 & 27.0 & 24.2 & 73.0 & 23.07 \\
\hline 6. & Isolate 6 & 42.48 & 29.0 & 29.1 & 71.0 & 50.00 \\
\hline 7. & Isolate 7 & 47.48 & 27.8 & 25.5 & 72.2 & 42.85 \\
\hline 8. & Isolate 8 & 54.41 & 31.3 & 25.2 & 68.7 & 35.71 \\
\hline 9. & Isolate 9 & 79.28 & 30.0 & 32.2 & 70.0 & 16.66 \\
\hline \multirow[t]{5}{*}{10.} & Isolate 10 & 45.47 & 28.7 & 27.0 & 71.3 & 45.45 \\
\hline & Control & 34.70 & 28.0 & 26.1 & 72.0 & 61.53 \\
\hline & $\mathrm{SE} \mathrm{m} \pm$ & 0.40 & 0.34 & 0.72 & & 0.55 \\
\hline & $\mathrm{CD}$ at $(5 \%)$ & 1.19 & 1.02 & 1.15 & & 1.65 \\
\hline & $\mathrm{CV}$ & 1.25 & 2.06 & 2.17 & & 2.60 \\
\hline
\end{tabular}




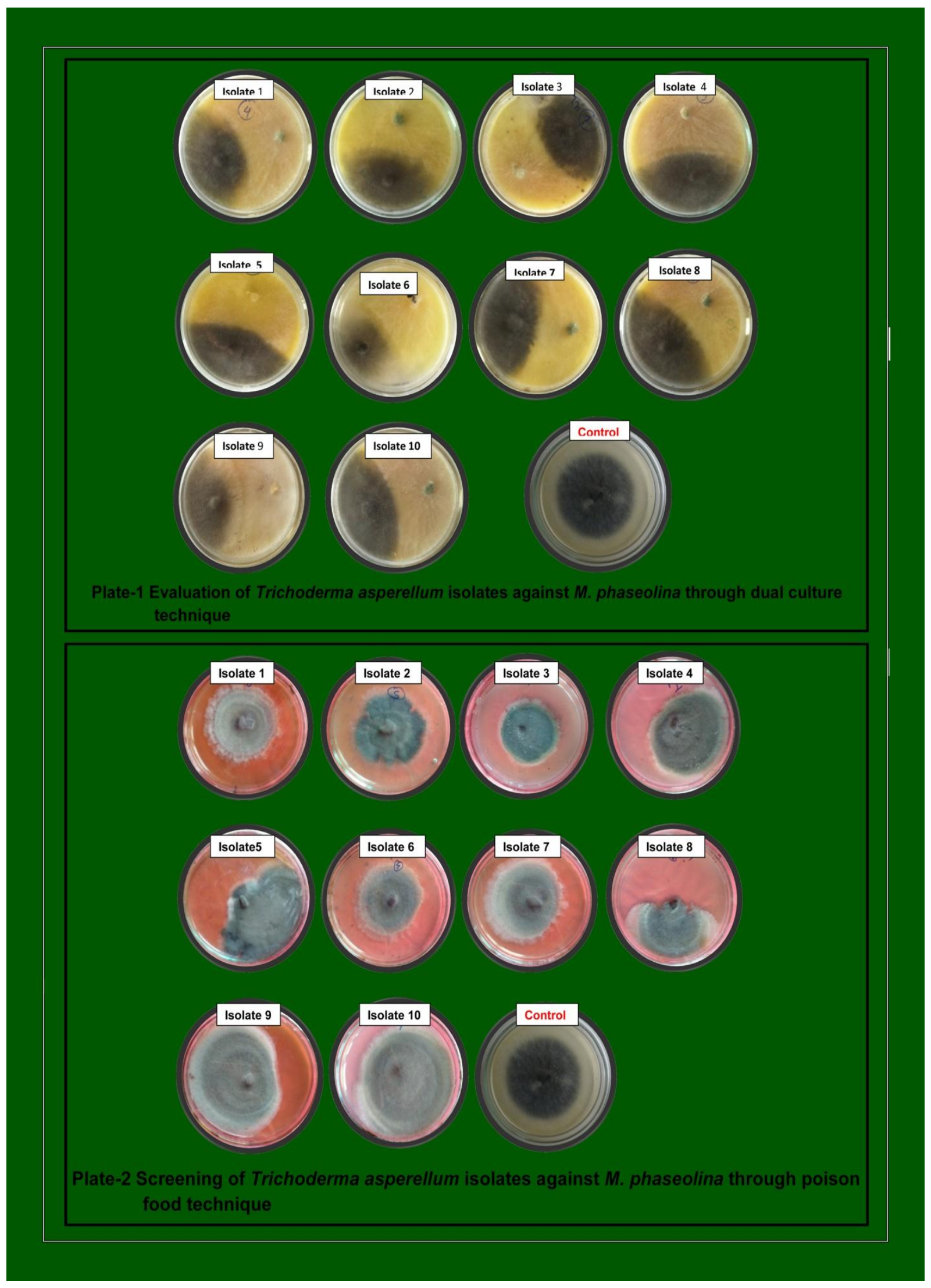


The chlorophyll content of leaves ranged between 27.0 to 32.2 in culture filtrate inoculated plants of different isolates prior to M. phaseolina inoculation while 18.9 to 32.2 percent in $M$. phaseolina inoculation plants. The highest chlorophyll content was recorded in isolate $9(32.2 \%)$ in $M$. phaseolina inoculated plants. Under the dual culture experiment, ten isolates of $T$. asperellum had shown strong antagonistic effect against $M$. phaseolina. The similar and the highest (16.3 $\mathrm{mm}$ and $17.0 \mathrm{~mm}$ ) mycelia growth suppression of test pathogen was recorded with isolate 4 and isolate 1 followed by 6 $(18.0 \mathrm{~mm})$ at $48 \mathrm{hrs}$ and $72 \mathrm{hrs}$ but the highest (35.0 and $35.7 \mathrm{~mm}$ ) suppression by isolate 6 and isolate 1 was recorded at 96 hours.

Such result could be due to faster growth and active parasitism by $T$. asperellum isolates. Member of Trichoderma species are known for their active hyperparasites of several soil fungi and hence they are used as a biocontrol agents (Ekefan et al., 2009). Karthikeyan et al., (2015) found that that T. harzianum and $T$. viride were effective against against $M$ phaseolina. Maximum reduction in the growth of Macrophomina was observed in the presence of native Trichoderma isolate, TW17 to an extent of 62.2 per was reported by Nagamani and Reddi Kumar (2015).

In poison food technique, the highest inhibition (18.3 and $50.3 \mathrm{~mm}$ ) was recorded in cell free culture filtrate of isolate 6 at 48 and 96 hours. The growth inhibition by isolate $8(22.7 \mathrm{~mm})$ was higher than isolate $3(25.3$ $\mathrm{mm})$ at 48 hours but not at 72 hours. However, both isolates (isolate 8 and isolate 3 ) became equally inhibitory towards the $M$. phaseolina at 96 hours. Such result may be attributed to the availability of nutrient in the medium and its impact on biocontrol mechanism of bioagents. Competition for carbon, nitrogen and iron mechanism associated with biocontrol has been proposed by Couteadier (1992). Tapwal and associates (2011) reported that non-volatile metabolites of $T$. viride were more effective against $R$. solani, Curvularia lunata and Alternaria solani. Metabolite of T. harzianum, T. viride and $T$. virens has been found to inhibit the mycelial growth of Fusarium oxysporum $\mathrm{f}$. sp. ciceri (Dubey et al., 2014). Trichoderma strains inhibit the infections caused by plant pathogens using different biocontrol mechanisms like competition, antibiosis, mycoparasitism, hyphal interactions, and enzyme secretion (Hajieghrari et al., 2008; Poovendran et al., 2011).

Under in-vivo conditions, the maximum RWC was recorded in $T$. asperellum isolate 9 $(79.28 \%)$ followed by isolate $5(75.69 \%)$. The higher RWC in different bioagent treated plants could be due to their ability to mitigate the adverse effect of pathogen. The mitigation of water stress, caused by test pathogen, by inoculation of culture filtrate of bioagents could be attributed to such result. Increased stomatal resistance and reduced transpiration rates in Vigna aconitifolia (Yadava et al., 1994) and sorghum (Pedgaonkar and Mayee, 1990) have been reported due to water stress and drought condition. Turkan et al., (2005) observed that the water deficit result in decreased RWC in bean. Higher RWC in different bioagent treated plants could be due to their ability to mitigate the adverse effect of pathogen. Charcoal rot undergoes rapid development under strong water content depletion (Pedgaonkar and Mayee, 1990), therefore, cultivars that show reduced water depletion rates and a stable cellular turgor are resistant to charcoal rot (Mayek-Perez et al., 2002). The minimum charcoal rot incidence was recorded in $T$. asperellum isolate 9 (16.66\%), among T. asperellum isolates. Trichoderma is an effective mycoparasitic strains against fungal plant pathogens under a wide range of adverse environmental conditions (Manczinger et al., 2002). 


\section{References}

Bai Z., Jin B., Li Y., Chen Jand Li Z. 2008. Utilization of winery wastes for Trichoderma viride biocontrol agent production by solid state fermentation. Journal of Environmental Sciences 20: 353-358.

Barrs H.D. and Weatherley P.E. 1962. A reexamination of the relative turgidity technique for estimating water deficits in leaves. Australian Journal of Biological Sciences 15: 413-428.

Couteaudier Y. 1992. Competition for carbon in soil and rhizosphere, a mechanism involved in biological control of Fusarium wilts. Biological control of plant diseases. Plenum Press. New York pp 99-104.

Dennis C. and Webster J. 1971. Antagonism properties of species groups of Trichoderma, III. Hyphal interaction. Transactions British Mycological Society 57: 363-369.

Dubey S.C., Priyanka K. and Singh V. 2014. Phylogenetic relationship between different race representative populations of Fusarium oxysporum f. sp. ciceris in respect of translation elongation factor 1- $\alpha, \beta$-tubulin, and internal transcribed spacer region genes. Archives of Microbiology 196: 445-452.

Ekefan E.J. Jama A. and Gowen S.R. 2009. Potential of Trichoderma harzianium isolates in biocontrol of Colletotrichum capsici causing anthracnose of pepper in Nigeria. Journal of applied bioscience 20: 1138-1145.

Hajieghrari B., Torabi-Giglou M., Mohammadi M.R. and Davari M. 2008. Biological potential of some Iranian Trichoderma isolates in the control of soil borne plant pathogenic fungi. African Journal of Biotechnology 7 (8): 967-972.
Karthikeyan V., Brindha S., Annadurai B. and Gangwar S.K. 2015. Biological control of $M$. phaseolina root rot in Vigna mungo (Black gram) with Trichoderma spp. I.J.A.B.R, Volume 5(2) 2015: 118127.

Malmierca M.G., Cardoza R.E., Alexander N.J., McCormick S.P., Hermosa R., Monte E., Gutiérrez S. 2012. Involvement of Trichoderma trichothecenes in the biocontrol activity and induction of plant defense-related genes. Applied and Environmental Microbiology 78 (14): 4856-4868

Manczinger L., Antal Z. and Kredics L. 2002. Ecophysiology and breeding of mycoparasitic Trichoderma strains (a review). Acta Microbiology Immunology Hung 49: 1-14.

Mayek-Perez N., Gracia-Espiosa R., LopezCastaneda C., Acosta-Gallegis J.A., Simpson J. 2002. Water relations, histopathology and growth of common bean (Phaseolus vulgaris L.) during pathogenesis of $M$. phaseolina under drought stress. Physiology Molecular. Plant Pathology 60: 185-195.

Nagamani P., Reddi K.M., and Sreedevi K.2015. Evaluation of genetically mutated Trichoderma spp. for the management of $M$. phaseolina, incident of charcoal rots of Sunflower. Current biotica 4 (4): 434-441.

Pearson C.A.S., Schwenk F.W., Crowe F.J., Kelly K. 1984. Colonization of soybean roots by Macrophomina phaseolina. Plant Disease 68: 1086-1088.

Pedgaonkar S.M. and Mayee C.D. 1990. Stalk water potential in relation to charcoal rot of sorghum. Indian Phytopathology 43: 192-196

Peng S., Garcia F., Laza R. and Cassman K.G. 1992. Leaf thickness affects the estimation of leaf using a chlorophyll meter. International Rice Research Newsletter 17(16): 19-20. 
Poovendran P., Kalaigandhi V. and Parivuguna V. 2011. In-vitro study of antagonistic effect of Trichoderma spp., on tea plant pathogen, Phomopsis theae. Archives of Applied Science Research 3(4): 352- 358.

Savazzini F., Longa C.M.O, Pertot I. 2009. Impact of the biocontrol agent Trichoderma atroviride $\mathrm{SC} 1$ on soil microbial communities of a vineyard in northern Italy. Soil Biology and Biochemistry 41: 1457-1465.

Tapwal A., Singh U., Jaime A., da Silva T., Singh G., Garg S. and Kumar R. 2011. Antagonism of Trichoderma viride against five Phytopathogens. Pest Technology 5 (1): 59-62.

Tesso T.T., Claflin L.E. and Tuinstra M.R. 2005. Analyses of stalk rot resistance and genetic diversity among drought tolerant sorghum genotypes. Crop Science 45: 645-652.

Thilgavathi R., Saravanakumar D., Ragupathy N., Samiyappan R. 2007. Integration of biocontrol agents for the management of dry root rots (M. phaseolina) disease in greengram. Phytopathol Mediterr 46: 157-167.

Turkan I., Bor M., Ozdemir F. and Koca H. 2005. Differential responses of lipid peroxidation and antioxidants in the leaves of drought tolerant $P$. acutifolius Gray and drought sensitive $P$. vulgaris L. subjected to polyethylene glycol mediated water stress. Plant Science 168: 223-231.

Verma M., Brar S.K., Tyagi R.D., Sahai V., Prévost D., Valéro J.R., Surampalli R.Y.2007. Bench-scale fermentation of Trichoderma viride on wastewater sludge: rheology, lytic enzymes and biocontrol activity. Enzyme and Microbial Technology 41 (6): 764-771.

Yadava S.G., Rathore G.S., Majumder V.L., Yadav V.K. and Yadava N. 1994. Stomatal response to $M$. phaseolina (Tassi) Goid. Infection in moth bean (Vigna acontifolia). Annals of Arid Zone 33: 91-92.

\section{How to cite this article:}

Ishwar Patidar and Vibha. 2018. Antagonism of Trichoderma asperellum Isolates against Macrophomina phaseolina Causing Soybean Charcoal Rot and Its Impact on Physiological Parameters of Crop. Int.J.Curr.Microbiol.App.Sci. 7(08): 1323-1331. doi: https://doi.org/10.20546/ijcmas.2018.708.150 